Terakreditasi: Sinta 4

\title{
Eksplorasi Jamur-Jamur yang Berasosiasi dengan Penyakit Mati Meranting pada Tanaman Kakao di Kota Padang
}

\author{
Exploration of Fungi Associated with Branch Dieback Disease on Cocoa in Padang City \\ Nurbailis $^{1)^{*}}$, Rummah Yulisyah ${ }^{2)}$, Novri Nelly') \\ 1) Jurusan Hama dan Penyakit Tumbuhan Fakultas Pertanian Universitas Andalas \\ 2) Program Studi Agroekoteknologi Fakultas Pertanian Universitas Andalas \\ E-mail: nurbailisjamarun@yahoo.co.id \\ Diterima:14 Februari 2021 Disetujui: 08 Mei 2021 Dipublikasi: 30 Juni 2021
}

\begin{abstract}
Branch dieback is one of the primary diseases in cacao plants. The disease affects young shoots and twigs, causes leaves to die, and leaves them bare, interfering with photosynthesis. This study aimed to determine the causative pathogens in Padang City. The locations were: Sungai Sarik Kuranji, Lubuk Minturun Koto Tangah, and Teluk Kabung Bungus. The locations have the following criteria: age $\geq$ three years, the number of plants at the location $\geq 50$ individuals, and found symptoms of branch dieback. The research used descriptive methods. The sample represented $10 \%$ of the total number of plants at the location, was collected randomly. The results found four species of fungi associated with the disease, namely Oncobasidium theobromae, Botrydiplodia theobromae, Fusarium decemcellulare, and Fusarium sp1.
\end{abstract}

Keywords: Botryodiplodia theobromae, cacao, dead twigs, Fusarium sp., Oncobasidium theobromae

\section{PENDAHULUAN}

Tanaman kakao (Theobroma cacao Louis) merupakan salah satu komoditas perkebunan yang memiliki prospek yang baik sebagai penghasil devisa negara. Areal pengembangan kakao di Indonesia meliputi Sulawesi Selatan, Sulawesi Barat, Sulawesi Tenggara, Sulawesi Tengah, Papua Barat, Jawa Timur, Lampung, Sumatera Barat, Sumatera Utara, dan Nanggroe Aceh Darussalam (Rubiyo dan Siswanto, 2011). Di wilayah Indonesia bagian barat, tanaman kakao banyak berkembang di Provinsi Sumatera Utara dan Sumatera Barat. Produksi kakao di daerah Sumatera Barat dari tahun 2016-2020 mengalami fluktuasi yaitu 52.153, 46.052, 58.980, 58.952, 54.100 ton (Direktorat Jendral Perkebunan, 2021). Sementara itu, Kabupaten Padang Pariaman merupakan salah satu sentra pengembangan kakao di Sumatera Barat dengan produksi 130, 15 ton pada tahun 2016. Sementara itu, produksi kakao di kota Padang masih rendah dibanding dengan potensi hasil kakao di Indonesia yang dapat mencapai 585.246 ton (Statistik Perkebunan Indonesia, 2019).

Penyakit mati meranting merupakan salah satu penyakit penting pada tanaman kakao yang menyerang pucuk dan ranting. Gejala yang ditimbulkan oleh penyakit mati meranting yaitu menguningnya daun kedua atau ketiga dari ujung ranting, yang diikuti 
dengan bercak hijau pada permukaan daun. Kemudian gejala berkembang sehingga seluruh permukaan daun berwarna kuning kecoklatan dan akhirnya gugur menyisakan ranting tanpa daun (Harni dan Baharuddin, 2014).

Di beberapa lokasi pertanaman kakao di Sumatera Barat telah ditemukan gejala penyakit mati meranting dengan gejala daun menguning sampai ke ujung ranting, dan pada bekas duduk daun terlihat tiga noktah berwarna coklat. Gejala lanjut menunjukkan daun gugur, ranting gundul, dan pucuk mati. Tanaman yang terserang akan meranggas dan kemudian mati secara perlahan. Insidensi penyakit antara 59-100\% dan keparahan penyakit 24,29-44,71\% (Trisno et al., 2015).

Penyakit mati meranting dikenal juga dengan Vascular streak dieback yang antara lain disebabkan oleh Botryodiplodia theobromae dan Fusarium. B. theobramae merupakan jamur yang bersifat polifag dan memiliki kisaran inang yang luas, baik di daerah tropis maupun subtropis di berbagai belahan dunia (Urbez-Torres et al., 2008). Nurhasanah et al. (2012) telah melaporkan keberadaan jamur ini pada tanaman jeruk, karet, manggis, pisang dan kakao. Arfani et al. (2013) juga menemukan adanya $B$. theobramae pada tanaman kakao.

Patogen tersebut merupakan saprofit fakultatif yang melakukan infeksinya melalui luka mekanis seperti akibat pemangkasan atau luka akibat serangga dan mempertahankan diri pada ranting, kulit cabang dan batang yang sakit. $B$. theobramae dapat menyebakan mati pucuk, busuk buah, dan kanker batang (Ardianti et al., 2017). Menurut Dhana et al. (2013), jamur penyebab mati meranting mempunyai miselium yang berwarna putih cream, yang bentuknya tebal seperti kapas, hifanya berdinding tipis, hialin dengan sekat (septa) kurang teratur, dan di ujungnya hifa akan terbentuk basidium. Basidium ini menghasilkan basidiospor yang berbentuk bulat telur dan salah satu sisinya rata, serta memiliki Panjang 10$15 \mu \mathrm{m}$ dan lebarnya 8-10 $\mu \mathrm{m}$. Sementara itu Fusarium sp. penyebab penyakit mati meranting dengan morfologi menunjukkan hifa yang menyebar ke segala arah membentuk miselium seperti kapas (Rahayu, 2015). Penelitian ini bertujuan untuk menentukan jenis jamur yang berasosiasi dengan penyakit mati meranting pada tanaman kakao di kota Padang.

\section{METODOLOGI}

Penelitian dilaksanakan pada Bulan Agustus 2017 sampai Januari 2018 di Laboratorium Fitopatologi, Jurusan Hama Penyakit Tumbuhan, Fakultas Pertanian, Universitas Andalas, Padang.

\section{Metode}

Penelitian ini menggunakan metode survei dan dilaporkan secara deskriptif. Kriteria lahan yang dipilih sebagai lokasi penelitian adalah memiliki jumlah tanaman kakao $\geq 50$ batang, berumur $\geq 3$ tahun, dan menunjukkan gejala mati meranting. Dari hasil survei ditetapkan 3 lokasi penelitian yaitu areal budidaya petani di Kelurahan Sungai Sarik Kecamatan Kuranji, Kelurahan Lubuk Minturun Kecamatan Koto Tangah, dan Kelurahan Teluk Kabung Kecamatan Bungus.

\section{Pelaksanaan}

\section{Pengumpulan sampel}

Sebanyak 10 tanaman kakao per lahan ditetapkan sebagai sampel secara acak. Ranting tanaman kakao yang menunjukkan gejala daun menguning, gugur, dan mati ranting, dipotong dengan menggunakan pisau dan ditempatkan dalam wadah plastik yang telah disediakan. Bagian tanaman kakao yang diambil dari tanaman sampel 
tersebut dibawa ke Laboratorium Fitopatologi Jurusan Hama dan Penyakit Tanaman, Fakultas Pertanian Universitas Andalas, untuk diisolasi dan identifikasi.

\section{Isolasi patogen}

Isolasi patogen dari ranting kakao dilakukan dengan metode moist chamber (Krug, 2004) yakni dengan meletakkan ranting tersebut dalam kotak hitam dan metode tanam langsung di media water agar (WA). Isolasi dengan metode moist chamber menggunakan kotak hitam bertujuan untuk merangsang pertumbuhan hifa pada daun dan ranting yang bergejala mati meranting.

Daun dan ranting yang bergejala dipotong dengan ukuran $1 \mathrm{~cm}^{2}$, kemudian dicuci secara bergantian dengan akuades, alkohol, dan akuades untuk selanjutnya diletakkan di atas kotak plastik yang berisi air dan dilapisi dengan kertas saring lembab. Kotak plastik tersebut dimasukkan ke dalam kotak hitam, ditutup rapat, dan diletakkan dalam ruangan dengan suhu $20^{\circ} \mathrm{C}$ dan diinkubasi selama 3-7 hari.

Sementara itu, metode tanam langsung dilakukan dengan cara mengambil ranting dan petiole tanaman kakao yang telah mati. Ranting dan petiole dipotong sepanjang $1 \mathrm{~cm}$. Selanjutnya, sebanyak 4-5 potongan tersebut diletakkan di dalam petridish kaca yang telah berisi medium WA, lalu diinkubasi selama 3 hari pada suhu kamar. Jamur yang tumbuh dipindahkan ke medium PDA sampai didapatkan biakan murni dari jamur tersebut, sehingga bisa diamati karakter makroskopis dan mikroskopisnya.

\section{Persiapan biakan jamur untuk identifikasi \\ Biakan murni jamur dipindahkan pada medium potato dextrose agar (PDA) dengan menggunakan cork borrer berdiameter $7 \mathrm{~mm}$ dan diinkubasi selama 14 hari. Persiapan biakan jamur untuk identifikasi dilakukan}

menggunakan metode slide culture (Jonson, 1972). Jamur ditumbuhkan pada medium PDA dan WA yang diletakkan pada object glass, dengan ukuran $1 \mathrm{~cm}^{2}$ di samping kiri dan kanan object glass lalu tutup dengan cover glass. Object glass diinkubasi dalam petridish plastik yang dialasi dengan tisu lembab dan ditumpu dengan pipet plastik dan tisu lembab. Pada hari ketiga dilakukan pengamatan secara makroskopis dan mikroskopis menggunakan Mikroskop Binokuler tipe X52.107BN.

\section{Pengamatan}

Kondisi pertanaman kakao dan karakterisasi gejala serangan di lapangan

Pengamatan gejala serangan penyakit mati meranting dilakukan saat pengambilan sampel di lapangan. Tanaman kakao yang menunjukkan gejala mati ranting diamati secara morfologi dan difoto untuk dokumentasi.

\section{Identifikasi jamur}

Identifikasi jamur di laboratorium dilakukan sampai genus dan spesies dengan berpedoman pada literatur Alexopolus (1996), Watanabe (2002), Leslie dan Summurell (2006). Pengamatan secara makroskopis dilakukan secara langsung yaitu dengan cara mengamati warna koloni (miselium), arah pertumbuhan dan penyebaran koloni jamur. Pengamatan secara mikroskopis, dilakukan di bawah mikroskop dengan mengamati konidia, hifa, klamidiospora, piknidia dan sekat, dan struktur lainnya dari jamur.

HASIL

\section{Kondisi Pertanaman Kakao dan Karakterisasi Gejala Serangan di Lapangan}

Masing-masing areal pengambilan sampel memiliki kondisi lingkungan yang secara umum sama yaitu tidak melakukan pemeliharaan yang baik terhadap tanaman 
kakao, seperti tidak melakukan pemangkasan dan tidak membuang bagian tanaman yang terserang. Ranting-ranting yang sakit dibiarkan berada di pohon, gulma dibiarkan tumbuh, dan petani juga tidak melakukan pemupukan (Gambar 1).

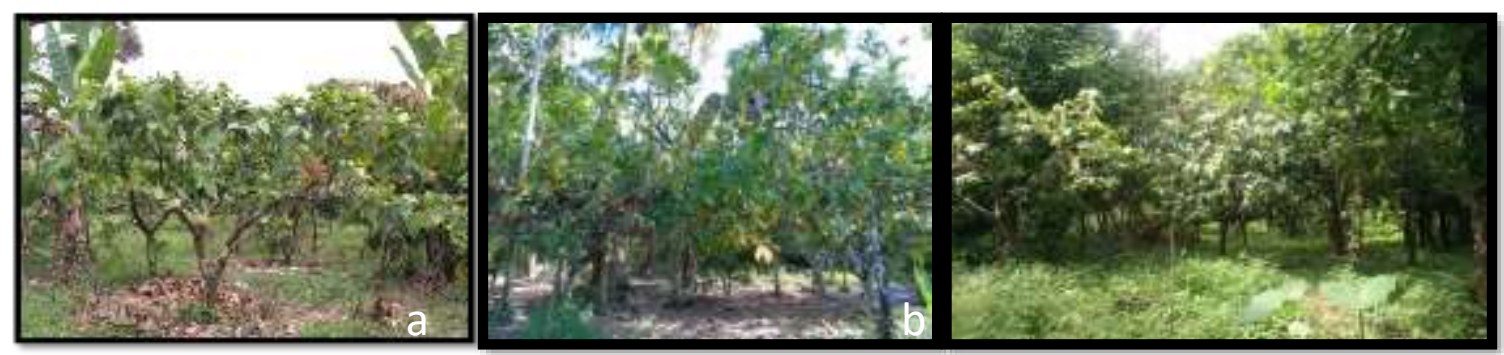

Gambar 1. Kondisi pertanaman kakao yang terserang mati meranting di lokasi penelitian: a. Kelurahan Sungai Sarik Kecamatan Kuranji, b. Kelurahan Teluk Kabung Kecamatan Bungus, c. Kelurahan Lubuk Minturun Kecamatan Koto Tangah

Berdasarkan pengamatan langsung di lapangan tempat lokasi penelitian diketahui bahwa tanaman kakao menunjukkan gejala terserang penyakit mati meranting (Gambar 2a). Gejala serangan yang ditimbulkan yaitu daun yang terinfeksi memperlihatkan perubahan warna menjadi kuning yang dimulai dari pinggir daun dan menyebar ke seluruh bagian daun. Kemudian, daun akan gugur dan ranting menjadi gundul (Gambar 2b). Klorosis pada daun dimulai dari bagian ujung daun kemudian menyebar keseluruh bagian tulang daun, selanjutnya daun menjadi nekrosis (Gambar 2c). Pada bagian batang terdapatnya bintik berwarna coklat pada bekas dudukan petiole daun (Gambar $2 d)$ yang menandakan terjadinya gangguan pada bagian pembuluh tanaman. Ranting kakao yang bergejala jika dibelah akan terlihat berwarna coklat pada pembuluh jaringan xylem (Gambar 2e).

\section{Bentuk Makroskopis dan Mikroskopis Jamur}

Dari hasil isolasi jamur yang berasal dari Kelurahan Sungai Sarik, Kecamatan Kuranji, Kelurahan Lubuk Minturun, Kecamatan Koto Tangah, dan Kelurahan Teluk Kabung, Kecamatan Bungus berhasil diidentifikasi empat jenis jamur dari empat isolat yaitu Oncobasidium theobromae, Botryodiplodia theobromae, Fusarium decemcellulae dan Fusarium sp1. Karakteristik ke empat jenis jamur tersebut adalah sebagai berikut:

\section{Isolat 1}

Pengamatan makroskopis pada isolat 1 dapat dilihat secara langsung yaitu adanya miselium berwarna putih yang terdapat pada tulang daun dan petiole yang ditanam langsung pada media WA. Berdasarkan pengamatan mikroskopis, hifa mempunyai percabangan tegak lurus dan mempunyai septum. Berdasarkan hasil pengamatan morfologi koloni secara makroskopis dan struktur secara mikroskopis di atas maka jamur ini termasuk ke dalam genus Oncobasidium dan diidentifikasi sebagai spesies Oncobasidium theobromae (Defitri, 2018) (Gambar 3).

\section{Isolat 2}

Karakteristik makroskopis dan mikroskopis dari isolat 2 yang berasal dari tiga kecamatan tidak berbeda satu sama lain. Pengamatan dari permukaan atas berwarna putih keabu-abuan dan lamakelamaan warna koloni menjadi abu-abu 

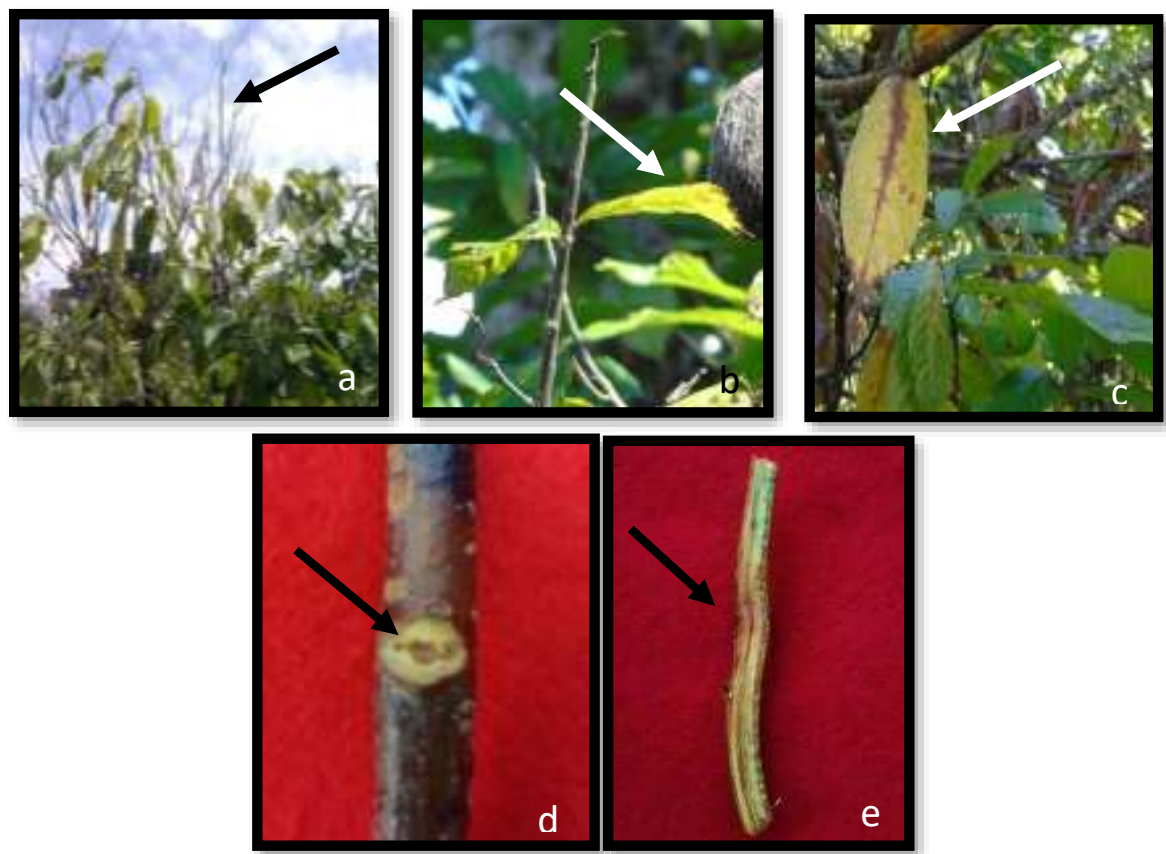

Gambar 2. Karakterisasi gejala penyakit di lapangan: a. gejala mati meranting pada tanaman kakao, b. ranting yang terserang menjadi gundul, c. klorosis pada daun, d. bekas dudukan daun ada bintik kecoklatan, e. pembuluh xylem akan tampak berwarna kecoklatan jika dibelah.
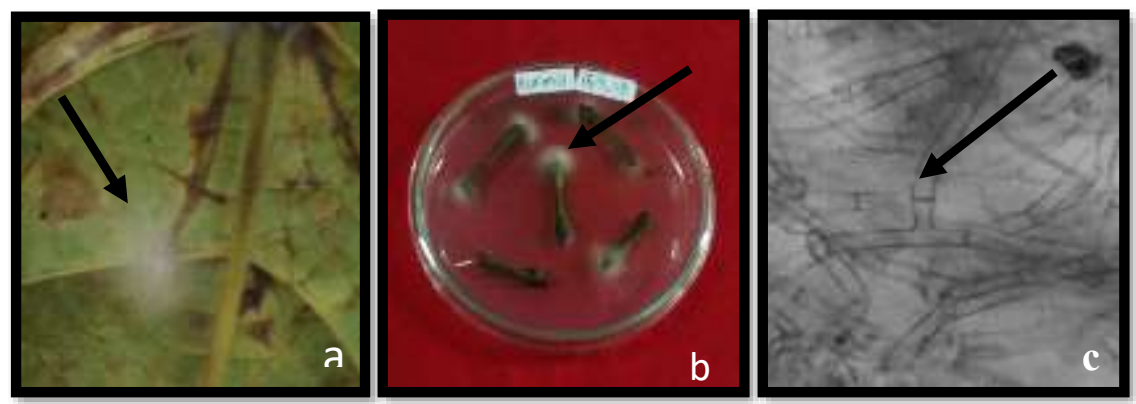

Gambar 3. Hasil isolasi dan mikroskopis jamur Oncobasidium theobromae: a. Jamur yang tumbuh pada tulang daun yang diinkubasi dalam kotak hitam, b. jamur yang tumbuh pada petiole daun pada medium water agar (3 hari setelah isolasi (hsi)), c. hifa yang tegak lurus dan mempunyai septum.

hingga hitam. Permukaan bawah berwarna hitam. Miselium seperti kapas dengan arah pertumbuhan ke samping dan ke atas. Pertumbuhan koloni sangat tebal dan penyebaran koloni melingkar. Untuk memenuhi petridish berdiameter $9 \mathrm{~cm}$ membutuhkan waktu 3-5 hsi. Jamur ini mempunyai tubuh buah yang disebut dengan piknidium. Hifa bersepta, bercabang dan berwarna putih ke abu-abuan serta memiliki klamidospora berbentuk rantai pada hifanya. Jamur ini memiliki dua tipe konidia, yaitu konidia muda dan konidia matang. Konidia muda berbentuk oval, hialin dan tanpa septum. Konidia matang berbentuk oval, berwarna coklat tua dan bersepta. Berdasarkan hasil identifikasi morfologi koloni secara makroskopis dan 
strukturnya secara mikroskopis diatas maka genus ini bisa diklasifikasikan jamur tidak sempurna, tergolong genus Botrydioplodia anggota spesies Botryodiplodia theobromae

(Alexopolus, 1996; Arfani et al., 2013) (Gambar 4).
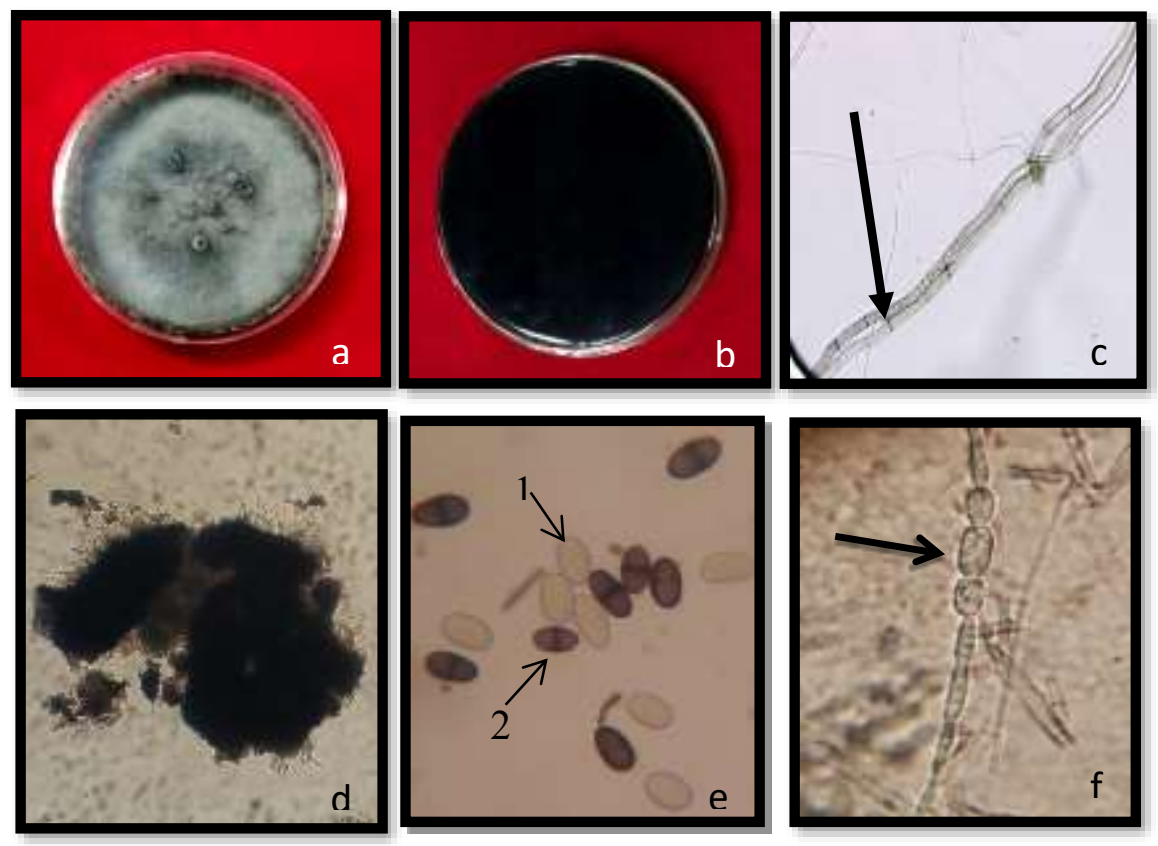

Gambar 4. Bentuk makroskopis dan mikroskopis jamur Botryodiplodia theobromae: a. koloni tampak atas, b. koloni tampak bawah, c. hifa bersepta (perbesaran 400x), d. piknidium (perbesaran 40x), e. konidia (1. muda, 2. tua) (perbesaran 40x), f. klamidospora (perbesaran 40x).

Isolat 3

Pengamatan yang dilakukan pada isolat 3 secara makroskopis (tampak atas) menunjukkan bahwa koloni berwarna putih kemerahan, arah pertumbuhan kesamping, dan tepi koloni rata. Permukaan miselium halus seperti kapas. Pengamatan koloni tampak bawah berwarna pink atau merah muda. Jamur ini membutuhkan waktu 14-15 hsi untuk memenuhi petridish yang berdiameter $9 \mathrm{~cm}$.

Pengamatan secara mikroskopis menunjukkan bahwa jamur ini memiliki dua konidia yaitu, mikrokonidia dan makrokonidia. Mikrokonidia jamur ini ada bersel 1, tidak memiliki septa dan ada yang bersel 2 dan memiliki satu septa, konidia hialin dan berdinding tipis. Makrokonidia berbentuk seperti bulan sabit yang kedua ujungnya runcing yang terdiri dari 6-8 sekat, hialin dan berdinding tipis. Konidia Jamur ini tersusun atas rantai dan false head.

Berdasarkan hasil identifikasi morfologi koloni secara makroskopis dan strukturnya secara mikroskopis, maka genus ini bisa diklasifikasikan sebagai jamur tidak sempurna termasuk dalam genus Fusarium, diidentifikasi sebagai spesies Fusarium decemcellulare (Leslie and Sumurrel, 2006; Arfani et al., 2013) (Gambar 5).

\section{Isolat 4}

Pengamatan yang dilakukan terhadap isolat 4 secara makroskopis memiliki koloni tampak atas berwarna putih kekuningan. Arah pertumbuhan koloni menyamping. Pertumbuhan koloni tidak rata dan permukaan miselium halus seperti kapas. Pengamatan koloni tampak bawah terlihat berwarna kuning. Jamur ini mempunyai hifa 


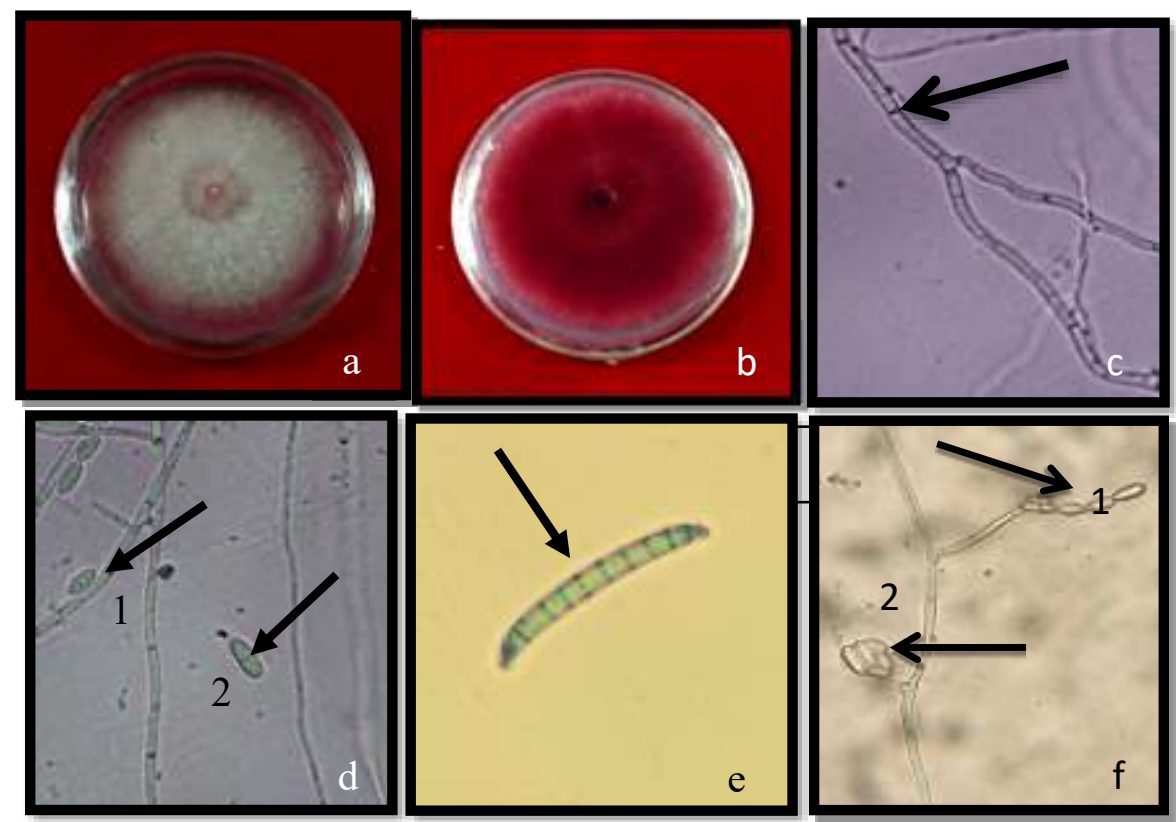

Gambar 5. Makroskopis dan mikroskopis jamur Fusarium decemcellulare : a. koloni tampak atas, b. koloni tampak bawah, c. hifa besepta (perbesaran 40x), d. mikrokonidia (1. tanpa septa, 2. bersepta) (perbesaran 400x), e. makrokonidia (perbesaran 40x), f. (1. rantai, 2. false head) (perbesaran 40x).

bersepta dan bercabang serta memiliki dua konidia yaitu, mikrokonidia dan makrokonidia. Mikrokonidia jamur tidak bersepta dan makrokonidia berbentuk seperti bulan sabit yang terdiri dari 5-6 septa. Berdasarkan hasil identifikasi morfologi koloni secara
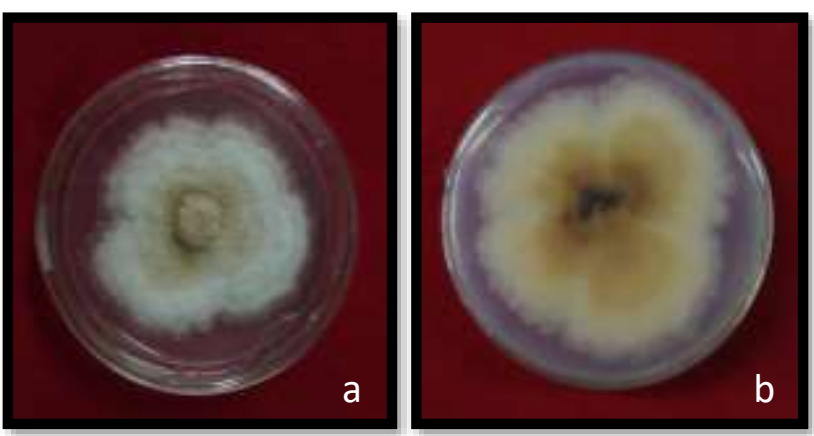

makroskopis dan strukturnya secar mikroskopis, maka genus ini bisa diklasifikasikan ke dalam jamur yang tidak sempurna tergolong genus Fusarium sedangkan spesies belum diketahui (Leslie and Summerrel, 2006) (Gambar 6).
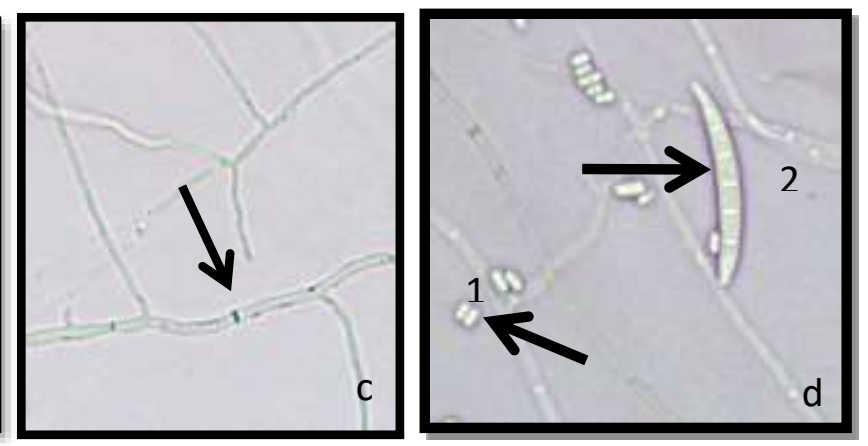

Gambar 6. Makroskopis dan mikroskopis jamur Fusarium sp.1 : a. koloni tampak atas, b. koloni tampak bawah, c. hifa bersepta (perbesaran 400x), d. konidia (1. mikrokonidia, 2. makrokonidia) (perbesaran 400x).

Karakteristik ringkas dari masing-masing jamur yang berasosisasi dengan penyakit meranting pada tanaman kakao dapat dilihat pada Tabel 1. 
Nurbailis et al. Eksplorasi Jamur yang Berasosiasi dengan Penyakit Mati Meranting

Tabel 1. Karakter makroskopis dan mikroskopis dari jamur yang berassosiasi dengan penyakit mati meranting pada tanaman kakao di kota Padang

\begin{tabular}{|c|c|c|c|c|}
\hline $\begin{array}{c}\text { Karakter } \\
\text { makroskopis }\end{array}$ & $\begin{array}{c}\text { Isolat } 1 \\
\text { Oncobasidium } \\
\text { theobromae }\end{array}$ & $\begin{array}{c}\text { Isolat } 2 \\
\text { Botryodiplodia } \\
\text { theobromae }\end{array}$ & $\begin{array}{c}\text { Isolat } 3 \\
\text { Fusarium } \\
\text { decemcellulae }\end{array}$ & $\begin{array}{c}\text { Isolat } 4 \\
\text { Fusarium sp1. }\end{array}$ \\
\hline $\begin{array}{l}\text { Warna koloni } \\
\text { tampak atas }\end{array}$ & Putih & $\begin{array}{l}\text { Putih keabu- } \\
\text { abuan }\end{array}$ & Putih & $\begin{array}{l}\text { Putih } \\
\text { kekuningan }\end{array}$ \\
\hline $\begin{array}{l}\text { Warna koloni } \\
\text { tampak bawah }\end{array}$ & Putih & Hitam & Merah muda & Kuning \\
\hline $\begin{array}{l}\text { Arah dan } \\
\text { Pertumbuhan } \\
\text { Koloni }\end{array}$ & - & $\begin{array}{l}\text { Kesamping, } \\
\text { keatas dan } \\
\text { melingkar }\end{array}$ & $\begin{array}{l}\text { Menyebar } \\
\text { dan } \\
\text { kesamping }\end{array}$ & $\begin{array}{l}\text { Menyebar dan } \\
\text { kesamping }\end{array}$ \\
\hline $\begin{array}{c}\text { Karakter } \\
\text { mikroskopis }\end{array}$ & $\begin{array}{c}\text { Isolat } 1 \\
\text { Oncobasidium } \\
\text { theobromae }\end{array}$ & $\begin{array}{c}\text { Isolat } 2 \\
\text { Botryodiplodia } \\
\text { theobromae }\end{array}$ & $\begin{array}{c}\text { Isolat } 3 \\
\text { Fusarium } \\
\text { decemcellulae }\end{array}$ & $\begin{array}{c}\text { Isolat } 4 \\
\text { Fusarium sp1. }\end{array}$ \\
\hline Hifa & $\begin{array}{l}\text { Tegak lurus dan } \\
\text { bersepta }\end{array}$ & $\begin{array}{l}\text {-Bercabang dan } \\
\text { bersepta } \\
\text {-Terbentuk } \\
\text { klamidospora } \\
\text { pada hifa }\end{array}$ & $\begin{array}{l}\text {-Bercabang, hialin } \\
\text { dan bersepta } \\
\text { - membentuk } \\
\text { rantai dan false } \\
\text { head }\end{array}$ & $\begin{array}{l}\text { Bercabang, } \\
\text { hialin dan } \\
\text { bersepta }\end{array}$ \\
\hline Tubuh buah & - & Piknidia & - & - \\
\hline $\begin{array}{l}\text { Konidia/ } \\
\text { Spora }\end{array}$ & - & $\begin{array}{l}\text { - Konidia muda } \\
\text { (oval, hialin dan } \\
\text { tidak bersepta) } \\
\text { - Konidia } \\
\text { matang (oval, } \\
\text { berwarna } \\
\text { cokelat } \\
\text { kehitaman dan } \\
\text { bersepta) }\end{array}$ & $\begin{array}{l}\text {-Mikrokonidia } \\
\text { (oval, hialin, } \\
\text { berdinding tipis, } \\
\text { memiliki } 0 \text { septa } \\
\text { dan } 1 \text { septa) } \\
\text {-Makrokonidia } \\
\text { (berbentuk bulan } \\
\text { sabit, kedua } \\
\text { ujungnya } \\
\text { runcing, hialin } \\
\text { berdinding tipis, } \\
\text { dan terdiri dari } \\
\text { 6-8 septa) }\end{array}$ & $\begin{array}{l}\text {-Mikrokonidia } \\
\text { (oval, hialin, } \\
\text { berdinding } \\
\text { tipis, memiliki } 0 \\
\text { septa) } \\
\text {-Makrokonidia } \\
\text { (berbentuk } \\
\text { bulan sabit, } \\
\text { hialin } \\
\text { berdinding } \\
\text { tipis, dan terdiri } \\
\text { dari 5-6 septa) }\end{array}$ \\
\hline
\end{tabular}

\section{PEMBAHASAN}

Tanaman kakao di areal penelitian menunjukan adanya gejala mati meranting. Gejala yang ditimbulkan oleh penyakit tersebut yaitu matinya ujung pada rantingranting kakao yang terlihat kecoklatan atau hangus, daun pada tanaman kakao berubah menjadi hijau kekuningan, lama-kelamaan akan berubah menjadi kocoklatan dan menggulung. Setelah gejala berlanjut, daundaun akan berguguran. Menurut Khuro et al. (2005), tanaman yang terserang penyakit 
mati meranting akan mengakibatkan aliran nutrisi dan air pada pembuluh floem dan xylem menjadi terhambat. Hasil identifikasi yang dilakukan di laboratorium diperoleh empat jenis jamur yang berasosiasasi dengan penyakit mati meranting yaitu: Oncobasidium theobromae, Botryodplodia theobromae, Fusarium decemcellulare dan Fusarium sp1.

Pengamatan makroskopis terhadap $O$. theobromae menunjukkan adanya miselium berwarna putih terdapat pada tulang daun dan petiole yang di tanam langsung pada media water agar. Berdasarkan pengamatan mikroskopis, hifa mempunyai percabangan tegak lurus dan mempunyai sekat. Evarina (2018), menyatakan bahwa jamur $O$. theobromae mempunyai hifa berwarna putih, tebal seperti kapas, hialin, berdinding tipis dengan septa kurang teratur dan di ujung hifa akan membentuk basidium. Basidium menghasilkan basidiospora yang berbentuk oval.

B. theobromae memiliki koloni berwarna putih keabu-abuan dan semakin lama warna koloni berubah menjadi warna abuabu dan hitam. Miselium seperti kapas dengan arah pertumbuhan rata ke samping. Hifa bersekat dan bercabang serta memiliki klamidospora. Jamur memiliki konidia muda (rangkaian akropetal) dan konidia matang. Konidia muda berbentuk oval dan tanpa sekat. Konidia dewasa berbentuk oval, berwarna coklat dan memiliki sekat. Timmer et al. (2000) menyatakan bahwa morfologi jamur B. theeobromae memiliki perbedaan antara konidia matang dengan konidia muda yaitu konidia matang berwarna coklat tua, memiliki sekat, terdiri dari dua sel. Jamur $B$. theobromae memiliki tubuh buah yang disebut dengan piknidium.

Fusarium spp., dari hasil isolasi dan identifikasi terdiri dari 2 spesies jamur yaitu Fusarium merah ( $F$. decemcellulare) dan putih kekuningan (Fusarium sp.1). F. decemcellulare, mempunyai miselium seperti kapas dengan arah pertumbuhan kesamping dan tepi koloni rata. Jamur ini membentuk pigmentasi berwarna merah muda pada biakan. Hifa bersekat, hialin dan bercabang. Aduacheampung (2009), menyatakan bahwa hifa jamur $F$. decemcellulare awalnya berwarna putih dan kemudian berwarna merah muda karena menghasilkan pigmen merah muda.

Jamur $F$. decemcellulare mempunyai makrokonidia dan mikrokonidia. Makrokonidia berbentuk bulan sabit dan memiliki 6-8 septa. Mikrokonidia berbentuk oval terdiri dari 1 sel, berdinding tipis dan hialin. Puspitasari (2016) mengemukakan bahwa $F$. decemcellulare memiliki 2 konidia, yaitu mikrokonidia dan makrokonidia. Mikrokonidia ada yang 1 sel dan ada yang bersel 2 (1 septa) yang berbentuk oval, hialin dan berdinding tipis. Makrokonidia berbentuk seperti bulan sabit terdiri dari 6-7 septa dan hialin serta berdinding tipis.

Penyakit mati meranting menyerang pertanaman kakao di kebun petani di kota Padang. Hal ini antara lain diduga karena budidaya tanaman kakao belum dilakukan secara optimal. Petani tidak melakukan pemangkasan, pemupukan, dan sanitasi kebun secara teratur. Tidak adanya pemangkasan mengakibatkan tanaman kakao menjadi rimbun sehingga kelembaban mikro menjadi tinggi dan memicu terjadinya perkembangan penyakit pada tanaman kakao. Menurut Wood dan Lass (1985), pemangkasan pada tanaman kakao sangat penting karena dapat menyediakan iklim mikro yang sesuai dan mendorong peningkatan produksi untuk tanaman kakao. Pemangkasan yang dilakukan secara efektif dan tepat waktu dapat mencegah dan mengurangi penyakit pada tanaman kakao. Hal ini sesuai dengan fungsi dari pemang- 
kasan yaitu agar tanaman tidak kehilangan nutrisi dan memicu tanaman untuk membentuk daun baru yang berdampak baik terhadap peningkatan kualitas buah (Baihaqi et al., 2015). Selain akibat pemangkasan, diperlukan adanya rorak atau lubang tempat penimbunan serasah di sekitar pertanaman yang secara alami dapat menyediakan bahan organik dan menyimpan air dengan baik (Bone, 2017).

Petani di tiap kebun juga tidak melakukan pemupukan secara rutin sehingga tanaman kakao menjadi kekurangan nutrisi dan unsur hara. Hal ini mengakibatkan produksi tanaman kakao menjadi berkurang. Tambunan (2009), menyatakan bahwa penambahan pupuk hayati yang dikombinasikan dengan bio-urine dapat meningkatkan berat buah kakao.

Sanitasi kebun tidak rutin dilakukan oleh petani sehingga adanya gulma dan sisasisa kulit buah dibiarkan berserakan di pangkal pohon kakao. Hal ini jika dibiarkan terus-menerus dapat mempengaruhi produksi kakao menjadi rendah karena persaingan unsur hara dan perkembangan penyakit akan lebih mudah. Asrul (2010), berpendapat bahwa adanya gulma di bawah pohon kakao akan menjadi pesaing unsur hara, sinar matahari, air, dan ruang serta membantu penyebaran hama dan penyakit.

\section{KESIMPULAN}

Penyakit mati meranting pada tanaman kakao di Kota Padang disebabkan oleh asosiasi empat jenis jamur yaitu Oncobasidium theobromae, Botryodiplodia theobromae, Fusarium decemcellulare, dan Fusarium sp1.

\section{DAFTAR PUSTAKA}

Aduacheampong RK. 2009. Pathogen diversity and host resistance in dieback disease of cocoa caused by Fusarium decemcellulare and Lasiodiplodia theobromae. Imperial College London. Silwood Park Campus. London.

Alexopoulos CJ, CW Mims, dan M Blackwell. 1996. Introductory mycology. $4^{\text {th }}$ Edition. John Wiley and Sons. New York.

Ardianti S, Umrah, dan Asrul. 2017. Pengamatan Oncobasidium theorbomae secara makroskopis dan mikroskopis, serta gejala serangan sebagai penyebab penyakit Vascular Streak Dieback (VSD) pada tanaman kakao di Kabupaten Sigi, Sulawesi Tengah. Biocelebes 11(2): 60-65.

Arfani MI, Yulianty, dan ML Lande. 2013. Inventarisasi jenis-jenis jamur pada tanaman kakao (Theobromae cacao L.) di Kabupaten Pesawaran. Jurnal ilmiah Biologi Eksperimen dan Keanekaragaman Hayati 1(2): 96-102.

Asrul L. 2010. Kajian monitoring dan evalusi gerakan nasional peningkatan produksi dan mutu kakao. Sulawesi Selatan Tidak dipublikasi.

Badan Pusat Statistik. 2019. Statistik Kakao Indonesia 2018. [Diakses tanggal $5 \mathrm{Mei}$ 2021].

Baihaqi A, A Hamid, A Anhar, Y Abubakar, T Anwar, dan Y Zazunar. 2015. Penerapan teknik budidaya serta hubungan antara pemangkasan dan peningkatan kesuburan tanah terhadap peningkatan produktivitas kakao di Kabupaten Pidie. Jurnal Agrisep 16(2): 54-61.

Junaedi, Sofyan, dan S Thamrin. 2017. Pemanfaatan limbah kulit kakao sebagai pupuk organik di Kecamatan Lamuru Kabupaten Bone. Jurnal Balireso 2(2): 73-82.

Dhana NP, L Lubis, dan Lisnawati. 2013. Isolasi jamur Oncobasidium theobromae PHB Talbot dan Keane penyebab penyakit Vascular Streak Dieback pada 
tanaman kakao di Laboratorium. Jurnal Online Agroekoteknologi 1(1): 288293.

Direktorat Jendral Perkebunan Indonesia. 2021. Komoditas kakao di Indonesia 2016-2020. Direktorat Jendral Perkebunan Indonesia. Jakarta.

Evarina. 2018. Identifikasi dan tingkat serangan patogen penyebab mati meranting tanaman kakao (Theobromae cacao) di Kabupaten Padang Pariaman. [Thesis]. Fakultas Pertanian. Universitas Andalas. Padang.

Harni R dan Baharuddin. 2014. Keefektifan minyak cengkeh, serai wangi, dan ekstrak bawang putih terhadap penyakit Vascular Streak Dieback pada Kakao. Jurnal Tanaman Industri dan Penyegar 1(3): 167-174.

Khanzada MA, AM Lodhi, dan S Shahzad. 2004. Mango dieback and gummosis in Sindh, Pakistan caused by Lasiodiplodia theobromae. Online. Plant Health Progress 10.

Khuro RD, SM Nizamani, MM Jiskani, dan QD Abbasi. 2005. Mango tree mortality in Sindh: Causes, symptoms and control strategies through IPM (Brochure). Faculty of Crop Protection, Sindh Agriculture University. Tandojam.

Krug JD. 2004. Moist Chamber for Development of Fungi. Elsevier Science \& Technology. Netherlands.

Leslie JF dan BA Summerell. 2006. The Fusarium laboratory manual. Blackwell Publishing Ltd. UK. London.

Nurhasanah, YS Mutaqim, KH Wiyono dan Suryo. 2012. Karakterisasi cendawan Botryodiplodia theobromae dan Rhizoctonia solani dari berbagai tanaman inang berdasarkan morfologi dan pola RAPD-PCR. Scientific
Repository IPB. [https://repository.ipb. ac.id/handle/123456789/56388].

Puspitasari M. 2016. Keragaman jamur yang berasosiasi dengan penyakit mati meranting pada tanaman mangga dan pengendaliannya dengan beberapa jenis fungisida nabati. Program Pascasarjana Universitas Andalas. Padang.

Rahayu A. 2015. Identifikasi molekuler Fusarium sp. penyebab penyakit Fusarium Vascular Streak Dieback pada tanaman kakao. Jurusan IImu Hama Penyakit. Universitas Hasanuddin. Makassar.

Tambunan TR. 2009. Kakao manajemen agribisnis dari hulu hingga hilir. Penebar Swadaya. Jakarta.

Timmer LW, PD Robert, HM Darhower, PM Bushong, EW Stover, TL Peever, dan AM Ibanez. 2000. Epidemiology and control Citrus greasyspot in different citrus growing area in Florida. Plant Disease Journal 84: 1294-1298.

Trisno J, Reflin, dan Martinius. 2016. Vascular Streak Dieback: Penyakit baru tanaman kakao di Sumatera Barat. Jurnal Fitopatologi Indonesia 12(4): $142-147$.

Urbez-Torres JR, GM Leavitt, JC Guerrero, J Gofuevara, dan WD Gubler. 2008. Identification and pathogenicity of Lasiodiplodia theobromae and Diplodia seratia, the causal agents of bot canker disease of grapevines in Mexico. Plant Disease Journal 92(4): 519-529.

Watanabe T. 2002. Soil and seed fungi, morphologis of cultured fungi and key to species. CRC Press. New York.

Wood GAR, dan LA Lass. 1985. Cocoa. $4^{\text {th }}$ Edition. Longman Group Lt. London. 